Global and Stochastic Analysis

Vol. 5 • No. 6 • Special Issue 2018

\title{
THE IMPLEMENTATION OF LIVING LABORATORY MODEL IN ACCOUNTING EDUCATION THROUGH PARTNERSHIP WITH SMES
}

\author{
SUPARTI, SUNARYANTO, BETY NUR ACHADIYAH AND DUDUNGMA'RUFNURIS
}

\begin{abstract}
SMEs is one of the economic resources in Indonesia. In their development, SMEs have several constraints. One of them is the financial statements that are not in accordance with the standards of Financial Accounting in Indonesia. SAK EMKM is issued to assist SMEs or MSMEs to complete their financial report. In an attempt made by universities to empower SMEs, through community service programs for students, appropriate and relevant models are required. Living Laboratory Model Development in accounting education is created through cooperation between universities and government through Department of Cooperatives and SMEs, in an effort to empower SMEs. This research used descriptive qualitative method with semi-structured interview to collect primary data. Objects used in SMEs Malang City are in accordance with the criteria contained in Act No. 20 of 2008. Data was analyzed by data reduction, data presentation, conclusion and verification. The results of this study indicate that the formulation and preparation of financial statements were in accordance with SAK EMKM in Lestari Jaya Furniture Business, consisting of: (1) Statement of financial position with total assets of $244,788,000$ IDR and total liabilities of $30,305,000$ IDR and equity of 114,646,900 IDR; (b) The company's net income represents the company's performance in 2017 amounted to $99,836,100$ IDR, and; (c) Notes to the financial statements present the general description of the company, the statement that the report was prepared using SAK EMKM as the basis for the preparation, as well as accounting policies applied and presented in the financial report of Lestari Jaya Furniture.
\end{abstract}

\section{Introduction}

In order to face the Asian Economic Community in 2015, all economic actors must be "international". It means that the products they produce, either in the form of goods or services, must be able to compete with other Asian products that freely entered Indonesia without any filter, including Small/Medium/Micro-Enterprise (SMEs). SMEs that make an extraordinary contribution to the economy of Indonesia must be able to not only survive domestically but also compete in the wider market,throughout Asia. Therefore, from all sides, SMEs must improve themselves in order to become international.

However, the development of SMEs not always runs smooth. Barriers are often confronted by SMEs actors, such as limited capital, low awareness, marketing difficulties, limited supply of raw materials, lack of skills or experience, inappropriate business locations and other problems. In addition, SMEs are also faced with various challenges in this global era, such as wide-open market opportunities, new technology entry, efficiency and productivity, and very tight competition with new players.

Keywords: Living Laboratory, SMEs, Financial Statements, SAK EMKM. 
These factors make SMEs empowerment not only a concern of the government, but also other sectors, such as Higher Education.

There are still many SMEs that are not yet fully aware of the usefulness of accounting. In fact, accounting is very beneficial for business development such as helping small businesses in taking a decision, facilitating in obtaining credit from creditors, and providing accurate and timely information. So that, any decision taken by the leader in developing the business will be based on the complete financial statements and which in fact is not just based on assumptions alone. Managing a company is not easy, no exception to SMEs The more complex a company's operational activities, the moreimportant the preparation of financial statements to apply. The result of the preparation of the financial statements is in the form of information that can be used to indicate the company's financial condition (Suhairi, 2014).

In preparing standardized financial statements, the system must be revamped by the company itself first, because a good system will facilitate the implementation. The Institute of Indonesia Chartered Accountant has authorized the Exposure Draft of Financial Accounting Standards of Micro, Small and Medium Enterprises in its meeting on May 18, 2016 and became effective as of January 1, 2018. Exposure Draft of Financial Accounting Standards of Micro, Small and Medium Enterprises are a way simpler financial accounting standard compared with the Financial Accounting Standards of Entities without Public Accountability. The issuance of the Financial Accounting Standard for Micro, Small and Medium Enterprises aims to be implemented in micro, small and medium entities as defined in the Financial Accounting Standards of Entities without Public Accountability, which meet the definitions and criteria of micro, small and medium enterprises as regulated in the prevailing laws in Indonesia.

The role of Higher Education is very important in the development of society. Effendi (2013) stated that currently the community trustshigher education as educational institution that still has the moral power to be the role model for society in the transformation towards global community. It is inevitable thathigher education has a huge role in empowering SMEs. In his research, Rasyid (2017) states the need for SMEs empowerment activities conducted by Higher Education with the assistance of government and related parties, so that SMEs can function as a driving force of populist economy. Therefore,Higher Education is expected to make new findings in the field of science and innovation that can improve the progress of society in terms of economy. Related to link and match between Higher Education and SMEs, there should be mutual cooperation,in whichHigher Education serves as learning resources and SMEs serve as partners in developing science and technology. The role of Higher Education is not in providing capital but rather in fostering the capabilities of SMEs, thus Higher Education is encouraging SMEs' ability to access capital.

On the other hand, Real Work Lecture is one of the subjects programmed for bachelor's students at Universitas Negeri Malang, both for educational programs and non-educational programs. Real Work Lecture is themedium and vehicle for students to implement Tri Dharma Perguruan Tinggi (The Three Pillars of Higher 
Education), especially the third dharma, namely the dedication to the society. Real Work Lecture includespractical courses that aim to train and equip students to apply their knowledge and learn to solve real problems that occur in society. Therefore, Real Work Lecture programat Universitas Negeri Malangis combined with the field of science of the students, so that the graduates of Real Work Lecture program actually have significant competence for the benefit of living in the society after they finish their study at Universitas Negeri Malang.

Departing from the problems of SMEs that have been stated above, it can be concluded that in theattempt of HigherEducation to empower SMEs through community service programs that involve students, appropriate and relevant models are required. Living Laboratory Model Development needs to be created by making cooperation between Higher Education and government through Department of Cooperatives and SMEs, as an effort to empower SMEs. The development of Living Laboratory model begins with research activities to examine the problems faced by SMEs actors in the real life. The results of this research will be used as a starting point for the development of educational materials for the empowerment of SMEs. The purpose of Living Laboratory Model Development is to contribute in a practical way by involving parties, in this case is Higher Education, in realizing the community service program, especially for the students through education on SMEs. On the other hand SMEs get science and technology transfer that are expected to be useful to overcome their business problems. The development of this model is expected to be used for reference model for profession work lecture which is currently applied as an electivecourse (Real Work Lecture) in Faculty of Economics at UniversitasNegeri Malang.

\section{Literature Review}

\section{Living Laboratoryin Accounting Education}

Living laboratory or often called living lab is a concept of research and innovation. The characteristics of a living laboratory are user-centered, open innovation ecosystems, commonly used in regional or local contexts (e.g. city and region), integrating simultaneously between research and innovation in real life in the form of public-private-community partnerships (Von Hippel 1986, Chesbrough 2003, Bilgram et al 2008, Almirall \& Wareham 2011).

This concept is based on a systematic co-creation approach by integrating research and innovation processes. It is integrated through co-creation, exploration, experimentation and evaluation of the use of innovative ideas, scenarios, concepts and related technologies in the real-life cases. It is usually used in cases involving the society using it, not only as the subject being observed but also as the source of creation. This approach allows all stakeholders involved to jointly give consideration or input to the general performance of a product or service. Such consideration can be made in the early stages of research and development and through all elements of the product's life cycle, from design to recycling (Kusiak \& Tang 2006). 
In its practice, living laboratory puts the public at the center of innovation and offers new concepts and solutions to the society's needs. Livinglaboratory changesthe users, in this case is society, from observed objects to co-creators of values, ideas and innovation (Mc.Phee et al., 2012). It provides an opportunity to instill complex ideas and prototypes within the community. This opportunity, in turn, can stimulate interaction, create institutional support for innovation, and reduce the failure of innovation (Pierson and Lievens, 2005). Therefore, the concept of living laboratory is often raised as a way to involve private companies, communities, researchers/ academics and public organizations to engage in mutually beneficial cooperation.

The activities of living laboratory in accounting education in this research refer to four main activities which put forward by Pallot (2009),includingco-creation, exploration, experimentation and evaluation.

\subsection{Co-creation}

In this stage, the researcher identified the causes of the weaknesses faced by the SMEs actors in preparing the financial statements. This identification was done by directly plunging into the field to meet SMEactors to capture the various complaints and obstacles faced by them as well as propose solutions to solve the problem.

\subsection{Exploration}

After the obstacles and problems were identified, the next activity was to dig deeper into the solution by involving the related parties: SME actors as users, the Department of Cooperative and SMEs as the official agencies that overshadow the government, and the researchers as academics who represent Higher Education to design appropriate detail scenarios to help SMEs overcome all obstacles encountered in the preparation of financial statements. At this stage, the researcher designed an appropriate model by using the Real Work Lecture program included in the college curriculum to direct this program into one of the media for the improvement of student competence by directly plunging into the field to provide SMEs guidance in the preparation of financial statements.

\subsection{Experimentation}

In this stage, the researchers as representatives of Higher Education try to apply living laboratory model in accounting education by involving students to participate in providing guidance in solving problems that occur in SMEs by examining the preparation model of financial statements based on SAK EMKM.

\subsection{Evaluation}

Evaluation was conducted to assess the effectiveness of living laboratory model developed as part of the model refinement. Assessment is not limited to the success of SMEs in any financial reporting, but also the whole aspects of living laboratory model that was developed, including in terms of the increased competence achieved by the students based on the results achieved in the learning outcomes in the Real Work Lecture program. 


\section{Small/Medium/Micro-Enterprise (SMEs)}

The criteria of Small/Medium/Micro-Enterprise (SMEs) have been regulated under the umbrella of Law Number 20 Year 2008 regarding SMEs; they classified based on total assets and turnover owned by a business entity as presented in Table 1 as follows:

Table

Criteria of SMEs

\begin{tabular}{llll}
\hline No. & Business Entity & \multicolumn{2}{c}{ Criteria } \\
\cline { 2 - 3 } \multicolumn{2}{l}{ Asset } & Turnover \\
\hline 1. & Micro Enterprise & 50 millions IDR at most & 300 millions IDR at most \\
2. & Small Enterprise & $>50$ millions IDR - & $>300$ millions IDR -2.5 \\
& & 500 millions IDR & billions IDR \\
3. & Medium Enterprise & $>500$ millions IDR - & $>2.5$ billions IDR - \\
& & 10 billions IDR & 50 billions IDR \\
\hline
\end{tabular}

Source: Ministry ofCooperatives andSMEs, 2012

\section{Financial Statement Preparation based on SAK EMKM}

The information of business entity's financial position consists of information about the assets, liabilities and equity of the business entity at a certain date; it is presented in the statement of financial position. These elements are defined as follows (SAK EMKM, 2016): (a) Assets are resources which are controlled by an entity as a result of past events; economic benefits are also expected to be obtained by the entity in the future, (b) Liabilities are current obligation of an entity, which arise from past events and whose settlement resulted in an outflow of entity resources containing economic benefits, (c) Equity is the residual right to the entity's assets after deducting its entire liabilities.

The information of entity's performance consists of information on earnings and expenses during the reporting period, and is presented in the income statement. (a) Income is the increase in economic benefits during the reporting period in the form of cash inflows or increases in assets, or decreases in liabilities which result in an increase in equity not originating from the contribution of investors; (b) Expenses are the decrease in economic benefits during the reporting period in the form of cash outflow or decrease in assets, or an increase in liabilities resulting in a decrease in equity not caused by distribution to investors.

Basic measurement of elements of financial statements in SAK EMKM is historical cost. The historical cost of an asset is the amount of cash or cash equivalent paid to acquire the asset at the time of acquisition. The historical cost of a liability is the amount of cash or cash equivalent received or the amount of cash expected to be paid to meet liabilities in the normal course of business.

Recognition of elements of the financial statements is the process of establishing a post in the financial statements or the incomestatement that meets the following criteria: (a) The economic benefits associated with assets, liabilities, income and 
expenses will surely flow into or out of the entity; (b) These items have measurable and reliable costs.

Disclosure is required when compliance with certain conditions in SAK EMKM is inadequate for the user to understand the effects of transactions, events and other conditions on the entity's financial position and performance. Fair presentation of financial statements requires the business entity to present relevant information, appropriate representation, comparability, and comprehension.

The business entity presents the financial statements comprehensively at the end of each reporting period. The financial statements at least consist of: (1) Statements of financial position at the end of the period; (2) The income statement during the period; and (3) Notes to the financial statements containing additional and relevant details of relevant posts.

The entity's financial statements include the following positions: (a) Cash and cash equivalents, (b) Accounts receivable, (c) Inventories, (d) Fixed assets, (e) Accounts payable, (f) Bank debts, and (g) Equity. The income statement of business entity includes the following items: (a) Income, (b) Financialburden, and (c) Tax expense. Notes to the financial statements include: (a) A statement that the financial statements have been prepared in accordance with SAK EMKM, (b) Summary of accounting policies, and (c) Additional information and certain details explaining important and material transactions which will be useful for users to understand the financial statements.

\section{Research Method}

\section{Type of Research}

The type of research used was descriptive qualitative. Qualitative descriptive research aims to explain, summarize the various conditions, various situations, or variables that arise in the society that becomes the object of the study based on what is happening, and then raise them to the surface of the character or description of the condition, situation, or variable (Bungin, 2010, p.36). Qualitative descriptive research was used in this study in order to explain the business management in the family business of Lestari Jaya Furniture.

\section{Determination of Research Informant}

The informants who were taken in this study came from the company; they helped the researchers find out how the management of family company. Internal element of the company in question is the element of the company that has a role in the operational activities of the company directly or just as a supervisor of the company. The informants were taken using snowball sampling.

\section{Research Objectand Subject}

The phenomenon or problem of research that has been abstracted into a concept or variable is referred to as the object of research (Ulber Silalahi, 2009: 191). The object of this research was the trial of the implementation of Living Laboratory Model in Accounting Education in Lestari Jaya Furniture Business. The subjects 
of the study were 5 students Force 2015, who participated in Real Work Lecture program from Department of Accounting, Faculty of Economics, Universitas Negeri Malang, and the owner of Lestari Jaya Furniture as a partner willing to cooperate in this research.

\section{Place and Time of Research}

The research was conducted from April to August 2018 at the location of the partner, Lestari Jaya Furniture,atDanauBratan Street number 19 in Malang City. The phone number is 0341-714833/HP 081249318443.

\section{Data Collection Technique}

In this research, the data collection method used was as follows:

a. Interview: It is data collection where the researcher has prepared a written plan containing questions focused on answering the research problem (Kuncoro, 2012, p.160). The type of interview used was semi-structured interviews(no pre-determined questions), except in very early stages as starting an interview by asking general questions in the study area (Daymon and Holloway, 2008, p.264). Interviews were conducted directly face-toface with the research informants.

b. Documentation:It is in form of company's documents containing company's profiles and photographs of observations in the field.

\section{Data Analysis Technique}

Data was analyzed using interactive analysis model consisting of three components,namely: 1) Data reduction, 2) Data presentation, and 3) Drawing conclusion and verification. (Seiddel in Moleong, 2012, p.248).

\section{Results and Discussions}

\section{A. Results}

The results of this study are presented as follows:

1. The Condition of Lestari Jaya Furniture Business

Lestari Jaya Furniture is one of the furniture companies in Malang;it was established in 2000. Lestari Jaya Furniture produces various kinds of furniture such as chairs, tables, cabinets, beds and so forth. Lestari Jaya Furniture \is a family-owned company whose management is held directly by the owner of the company. Family company is a phenomenon in the business world. In addition to the very large number, family company also has a significant share for the state income (Susanto, 2005). In managing a family company, good management is required, consisting of several processes to manage each resource owned in an attempt to achieve company goals. The management processes consist of planning, organizing, driving, and controlling (Stoner, in Umar 2003, p.18).

In managing Lestari Jaya Furniture, the capital used by the owner of the company was derived from his own capital and from bank loans; while in obtaining 
the workforce, the recruitment process is not formal because it does not consider many requirements that are too complicated; the prospective employeesmust have the skills, tenacity and patience in the field of furniture, which can be seen from the results of their work and their perseverance in the work. This is because in the process of production, skill and persistence is highlyrequired. Therefore, the employees working in Lestari Jaya Furniture Business did not experience training process. As for finance, the owner of the company has been managingthe corporate finance by himself. The owner of the company is only assisted by the financial department, which is in charge of financial records; this task is performed by the wife of the owner of Lestari Jaya Furniture. Each financial transaction, such as incomeand expenditure, is made directly by the owner of this company.

Organizational structure in a business entity is needed to achieve business goals and run the business smoothly; therefore,an organizational structure is necessary. The organizational structure of Lestari Jaya Furniture Business is very simple because it is managed by Mr. Andi Amrullah Mahmud himself. The owner established a furniture business based on the thought that every household requires home furnishings or furniture, especially tables, chairs, cabinets, beds and others.

Market potential tends to grow in line with the growing number of new houses being built each year and the number of young families who still need furniture for the first time and those who need to replace their old furniture. Currently, the biggest demand for the product is through order. Generally, consumers come to showroom, some buy ready-made products directly, and some order products according to themodel and size preferred. Consumers of furniture companies are generally individuals but there are also some who buy on behalf of agencies, both government and private agencies.

\section{Financial Statement Preparation of Lestari Jaya Furniture}

\subsection{Determining Fiscal Period}

The fiscal period used by Lestari Jaya Furniture is one-year period, starting from December 1, 2017 until December 31, 2017. The selected period was adjusted to the due date of the company's expense to facilitate Lestari Jaya Furniture Business in fulfilling its obligations.

\subsection{Making Initial Balance Sheet}

Before making initial balance sheet, firstly identification of the financial condition of Lestari Jaya Furniture Business was conducted at the end of the period. From the data obtained, a list of account names was made in accordance with the financial transactionswhich are often made by the SME. If you want to make an initial balance sheet with a new fiscal period, then the final balance of the previous fiscal period must be input manually. The information ofpreparation of the initial balance sheet, the beginning balance data of some items was obtained from the results of interviews with Lestari Jaya Furniture. 


\section{Creating journal}

Journaling process was done to write all transactions that occurred. This transaction will affect two or more existing accounts.

\section{Posting to the ledger}

Ledger is structured to make it easier to view transactions per account in detail.

\section{Preparing Financial Statements}

Financial statements are prepared under SAK EMKM under the accrual basis.

\subsection{Creating a Balance Sheet}

The balance sheet provides information on the assets, liabilities and equity held by the Lestari Jaya Furniture in the period of December 2017. The balance sheet can be seen in Table 1 below.

\section{LESTARI JAYA FURNITURE FINANCIAL POSITION STATEMENT \\ Period 2017}

\begin{tabular}{ll}
\hline ASSETS & \\
Current Assets & \\
Cash & $14,113,000 \mathrm{IDR}$ \\
Savings in BRI & $23,005,000 \mathrm{IDR}$ \\
Account Receivable & $16,300,000 \mathrm{IDR}$ \\
Inventory & $91,550,000 \mathrm{IDR}$ \\
Wood Sanding Inventory & $\underline{2,620,000 \mathrm{IDR}}$ \\
Total Current Assets & $\mathbf{1 4 7 , 5 8 8 , 0 0 0 ~ I D R}$ \\
Fixed Assets & \\
Wood Sanding Compressor & $16,300,000 \mathrm{IDR}$ \\
AccumulatedDepreciation & \\
Wood Sanding Compressor (-) & $3,700,000 \mathrm{IDR}$ \\
Store Furniture & $7,300,000 \mathrm{IDR}$ \\
Accumulated Depreciation & \\
Store Furniture (-) & $1,900,000 \mathrm{IDR}$ \\
Pick-up Car & $82,000,000 \mathrm{IDR}$ \\
Accumulated Depreciation & \\
Pick-up Car (-) & \\
Total Fixed Assets & $\underline{2,800,000 \mathrm{IDR}}$ \\
Total Assets & $\underline{\mathbf{9 7 , 2 0 0 , 0 0 0 ~ I D R}}$ \\
& \\
LIABILITIES \& EQUITIES & \\
LIABILITIES & \\
$\quad$ Accounts Payable & \\
$\quad$ KUR BRI & \\
Total Liabilities & \\
\end{tabular}


EQUITIES

Owner's Capital $\quad 114,646,900$ IDR

Retained Earnings $\quad \underline{99,836,100 \mathrm{IDR}}$

Total Equities $\quad \underline{\underline{214,483,000 ~ I D R}}$

Total Liabilities \& Equities $\quad 244,788,000$ IDR

Source: Financial Statements of "Lestari Jaya Furniture"

\subsection{PreparingIncome Statements}

The income statement of a period indicates the company's financial performance during the period. Income statement can be seen in Table 2 below.

\section{LESTARI JAYA FURNITURE \\ INCOME STATEMENT}

Period2017

\section{REVENUE}

Furniture Sales

Revenue from Furniture Service

Total Revenue

Cost of Goods Sold

Purchase of Semi-Finished Goods

Process Cost

TotalCost of Goods Sold

Gross Profit

\section{EXPENSES}

Employee Salary

Telephone

Credit

Electricity

Water

Store Maintenance

THR (Lebaran Allowance)

Fixed asset depreciation

Total Expenses

Profit before Tax109,100,000 IDR

Other Expenses

Advertisement Tax

SME Tax (PPh (Income Tax)Article 21)

Profit after Tax

Zakat al-Mal

Net Profit

Source: Financial Statements of "Lestari Jaya Furniture"
420,400,000 IDR $\underline{25,300,000 \mathrm{IDR}}$

$445,700,000$ IDR

150,400,000 IDR 40,600,000 IDR

191,000,000 IDR

254,700,000 IDR

120,000,000 IDR

1,200,000 IDR

2,400,000 IDR

4,800,000 IDR

1,800,000 IDR

3,000,000 IDR

4,000,000 IDR

8,400,000 IDR

$145,600,000 \mathrm{IDR}$

2,500,000 IDR

4,204,000 IDR

$6.704,000 \mathrm{IDR}$

102,396,000 IDR

2,559,900 IDR

99,836,100IDR 


\subsection{Preparing Notes to theFinancial Statements}

Notes to the financial statements include:

a. A statement that the financial statements have been prepared in accordance with SAK EMKM.

b. Summary of accounting policies

c. Additional information and specific account details that describe important transactions and material, so that it is useful for users to understand the financial statements.

The type of additional information and details presented depends on the type of business activity undertaken by the business entity. Notes to the financial statements are presented systematically as long as they are practical. Each account in the financial statements refers to related information in the notes to the financial statements. Notes to the Financial Statements are presented below.

\section{LESTARI JAYA FURNITURE \\ NOTE TO FINANCIAL STATEMENT \\ Period2017}

1. GENERAL

Lestari Jaya Furniture, which is owned by Mr. Andi Amrullah Mahmud, was established on December 22, 2000 and started operating in early 2001; it has been listed as one of Micro, Small and Medium Enterprises located at Danau Bratan Street Number 19, Sawojajar Village, Kedungkandang Sub-district, Malang City.

\section{IMPORTANT SUMMARY OF ACCOUNTING POLICIES}

a. Statement of Compliance

The financial statements were prepared using the Financial Accounting Standards of Micro, Small and Medium Enterprises.

b. Basis for Preparation

The basis for the preparation of financial statements is the historical cost and the currency used for the preparation of the financial statements, Indonesian Rupiah.

c. Fixed Assets

Fixed assets are depreciated using a straight line with economic estimated life as follows:

Wood Sanding Compressor $=5$ years

Store Furniture $\quad=5$ years

Pick-up Car $\quad=10$ years

d. Revenue and Expense Recognition

Revenue and expenses will be recognized as soon as cash inflows and outflows.

3. DESCRIPTION OF ACCOUNTS IN BALANCESHEET

a. Assets

1) Wood Sanding Compressor worth $16,300,000$ IDR is a tool for finishing furniture. 
2) Store furniture is worth $7,300,000$ IDR, consisting of 1 table and 3 chairs to serve consumers.

3) Pick-up car worth $82,000,000$ IDR is a means of transportation for delivering goods to consumers.

b. Capital

Capital of 214,483,000 IDR was derived from the owner's capital and debt.

\section{DESCRIPTION OF ACCOUNTS IN INCOME STATEMENT}

a. Revenues

Revenues of 420,400,000 IDR came from furniture sales, both in cash and credit, for 12 months; and revenues of 25,300,000 came fromfurniture service for 12 months.

b. Expenses

1) Employee Salary of $120,000,000$ IDR for 2 workforces finishing furniture, consisting of 1 person in marketing and 1 person as driver; the salary is 2,500,000 IDR/ month respectively. It isin accordancewith the Regulation ofthe Governor of East Java No. 75 of 2017 about the determination of MSE in Malang City amounted to 2,470,073.29 IDR.

2) Expenses for store maintenance of 3,000,000 IDR for labor costs in repairing broken parts and so forth.

3) THR (Lebaran allowance) of 4,000,000 IDR for 4 employees, 1,000,000 IDR for each employee, was given on Eid al-Fitr.

\section{Implication}

Based on the results of Living Laboratory Model Development created through cooperation between Higher Education and the partner, Lestari Jaya Furniture, several implications can be described as follows:

1. Entrepreneur can know the actual condition of his company and can measure their performance in running his business.

2. Entrepreneur knows the development of his company from time to time, either the development of turnover and profit/loss.

3. Entrepreneur knows the losses early on, so bankruptcy can be avoided.

4. Entrepreneur knows the source and the use of business funds, so it can evaluate the financial performance of the business entity.

\section{Conclusions}

Based on the results and discussion of this research, it can be concluded that:

1. Development of Living Laboratory model in accounting education was donethrough cooperation between UniversitasNegeri Malang through Real Work Lecture program and government through Department of Cooperatives and SMEs in an attempt effort of empowering SMEs. Living Laboratory Model in accounting education was realized by assisting Lestari Jaya Furniture in preparing financial statements based on SAK EMKM. 
2. Financial statements of Lestari Jaya Furniture which was compiled by the owner and researchers based on SAK EMKM presents financial position presented period of year 2017 indicated total assets of the company of 244,788,000 IDR, total liabilities of 30,305,000 IDR and equity of 114,646,900 IDR; the net income of company showing the company's performance in 2017 amounted to 99,836,100 IDR. Notes to the financial statements present the general description of the company, the statement that the preparation of the financial statements uses SAK EMKM as the basis for the preparation, and the accounting policies adopted and presented in the financial statements of Lestari Jaya Furniture.

\section{References}

1. Abubakar Arif. 2004 Akuntansi Untuk Bisnis Usaha Kecil dan Menengah. Jakarta: Grasindo.

2. Basri, Y.Z. and M. Nugroho. 2009.Ekonomi Kerakyatan: Usaha Mikro, Kecil, dan Menengah. Jakarta: Penerbit Universitas Trisakti.

3. Bungin, Burhan. 2010. Analisis Data Penelitian Kualitatif, Edisi1.Jakarta : PT. Raja Grafindo Persada.

4. Effendi Rizal.2013. Accounting Principles "Prinsip-prinsipAkuntansiBerbasis SAK ETAP".Edisi Revisi Jakarta : PT. Rajagrafindo Persada

5. IkatanAkuntan Indonesia. 2016. Standar Akuntansi Keuangan Entitas Mikro, Kecil, dan Menengah,.Jakarta : Dewan Standar Akuntansi Keuangan

6. Moleong, Lexy J. 2012. Metodologipenelitiankualitatif. Bandung: PT. Remaja Rosdakarya

7. Pallot, M, B. Trousse, B. Senach, S. Richir, B. de Ruyter, W. Prinz, O. Rerolle, B. Katzy. 2008, Living Lab Research, ECOSPACE Newsletter Special Issue on Living Labs, Published by the ECOSPACE Consortium

8. Pallot, M, B. 2009. The Living Lab Approach: A User Centred Open Innovation Ecosystem.Webergence Blog (http://www.cweprojects.eu/pub/bscw.cgi/715404).

9. Suryono.2011. FungsidanPeran Usaha Kecil danMenengah. Jakarta, SalembaEmpat.

10. Suhairi. 2014. Personality, Accounting Knowledge, Accounting Information Usage and Performance A Research On Entrepreneurship of Indonesia Medium Industries, Disertasi. USM, Malaysia.

11. Undang-UndangRepublik Indonesia Nomor 20 Tahun 2008 Tentang Usaha Mikro, Kecil, danMenengah.

12. Warsono, S. dan E. Murti. 2010.Akuntansi UMKM TernyataMudahDipahamidan

13. Dipraktikkan.Yogyakarta: Asgard ChapterWinarno.

14. Wilson. Yvonne; Wilson.Michael; Clarke. Edward A. 2013. Accounting : An introduction toPrinciples and Practice. 8th Revised edition.Publisher Cengage Learning Australia.

15. Weygandt, Jerry J. 2015. Financial Accounting IFRS Edition.Publisher John Wiley \& Sons Inc.

Suparti, Sunaryanto, Bety Nur Achadiyah and DudungMa'rufNuris: Faculty of Economics, UNIVERSITASNEGERI MALANG, Indonesia 